\title{
Relationship Between DHI Production Values and Myers-Briggs Type Indicator As a Measure of Management Ability ${ }^{1}$
}

\author{
A. J. Young and J. L. Walters \\ Animal, Dairy and Veterinary Sciences Department \\ Utah State University, Logan 84322
}

\begin{abstract}
Associations between owners' Myers-Briggs Type Indicator $(\mathrm{MBTI})$ preferences $(\mathrm{E}=$ extraversion vs. $\mathrm{I}=$ introversion; $\mathrm{S}=$ sensing vs. $\mathrm{N}=$ intuition; $\mathrm{T}=$ thinking vs $\mathrm{F}=$ feeling; $\mathrm{J}=$ judging vs. $\mathrm{P}=$ perceiving) and 21 Dairy Herd Improvement (DHI) production variables were determined on 60 farms. Of 60 dairy farmers participating, 51 were from Holstein farms $(85 \%)$ and nine from farms with other breeds, primarily Jersey. Cows were milked either twice ( $n=44$ herds, $73 \%)$ or three times $(\mathrm{n}=16)$ per day. Farmers were evenly split between the "E" and "I" dimension, whereas $93 \%$ of the farmers were "S," 75\% "T," and 62\% "J.". Individuals with a preference for the "I" dimension were associated with higher peak and mature equivalent milk yield than those individuals with a preference for the "E" dimension. The "T" and "J" dimensions had a significantly higher percentage of the herd with records usable by USDA and a lower percentage of animals pregnant by the goal set by the dairy producer than the "F" and "P" dimensions. Herds managed by individuals with a combination preference of " $\mathrm{E}$ " and "P" produced 7 to 10 $\mathrm{kg}$ of $3.5 \% \mathrm{FCM} / \mathrm{cow}$ per day less or 1820 to $2752 \mathrm{~kg} /$ cow RHA ECM less than other combinations of the "EI" and "J-P" dimensions. Those herds also had longer days dry and a lower percentage of records usable by USDA, suggesting that the "E-P" preference is less favorably associated to those measures of herd performance. The MBTI had limited association with many DHI production variables, but relationships to measures of labor and business management should be examined.
\end{abstract}

(Key words: dairy herd management, Myers-Briggs type indicator, management)

\footnotetext{
Received September 27, 2001.

Accepted January 24, 2002.

Corresponding author: A. J. Young; e-mail: alleny@ext.usu.edu.

${ }^{1}$ This research was supported by the Utah Agricultural Experiment Station, Utah State University, Logan 84322-4810. Approved as journal paper no. 7408 .
}

\begin{abstract}
Abbreviation key: $\mathbf{E}=$ extraversion, $\mathbf{F}=$ feeling, $\mathbf{I}=$ introversion, $\mathbf{J}=$ judging, $\mathbf{M B T I}=$ Myers-Briggs Type Indicator, $\mathbf{N}=$ intuition, $\mathbf{P}=$ perceiving, $\mathbf{S}=$ sensing, $\mathbf{T}$ $=$ thinking.
\end{abstract}

\section{INTRODUCTION}

Dairy farmers make many decisions that have economic consequences for the profitability and survivability of their business. Making decisions comes under the general heading of management. Farmers are having to become better managers and manage their dairy as a business, including spending more time managing people and less time working directly with cows.

The concept of what constitutes a "good" dairy manager has historically been defined as how close production measures on a dairy come to those of the "ideal" dairy. Production measures are measured using an onfarm record system, DHI, and/or other records that mark individual data in the herd. Unfortunately, this type of analysis does not include two important pieces of information: the financial impact associated with the production results and the subjective reasons used by dairy farmers to make decisions.

Ford and Shonkwiler (1994) used statistical methods to determine that dairy managerial and financial managerial abilities were significant variables in explaining net dairy farm income. They also determined that dairy, financial, and crops management abilities were all negatively correlated with each other, suggesting that a dairy manager who is trying to manage all three facets personally will be less financially successful than a person who concentrates on one area. Focusing on the dairy aspect was suggested as the preferred economic choice.

The subjective portion of the decision process has been looked at by comparing farmers' attitudes with some production measure that may use a subjective decision process, such as culling (removal) of cows from the herd (Bigras-Poulin et al., 1985; Tarabla and Dodd, 1990; Beaudeau, 1995; Bascom, 1996). Those studies have shown that farmer attitudes are equal to or better at explaining farm performance than production measures alone. 
Objectively evaluating the subjective decision-making process on a dairy farm is difficult due to the lack of a "good" test. Research in education has used learning style/preference tests for many years and these may provide an objective test needed in agriculture. Gregorc (1979) remarks: "Learning style (personality preference) is a set of distinctive behaviors which serve as indicators of how a person learns from and adapts to his/her environment. It also gives clues as to how a person's mind operates." Learning styles assess (describe) the process that learners implement to organize and process information (Cano et al., 1992).

The Myers-Briggs Type Indicator (MBTI) is an instrument based on Jung's theory of psychological types (Myers and McCaulley, 1985). This instrument is capable of identifying 16 different personality types, and it accounts for most of the traits identified by other widely used instruments (Lawrence, 1984). When identifying differing personality types, the MBTI is considered to be the most reliable and valid instrument of its kind (Bonham, 1988).

The MBTI characterizes personality types by a combination of four dimensions or preferences, with a total of 16 possible combinations (types). The four dimensions characterize a person's preference, on a continuum between two extremes, for each of four pairs: Extroversion $(\mathbf{E})$ versus introversion $(\mathbf{I})$; sensing $(\mathbf{S})$ versus intuitive (N); thinking (T) versus feeling (F); and judging $(\boldsymbol{J})$ versus perceiving ( $\mathbf{P}$ [Lawrence, 1984; Myers and McCaulley, 1985]). The "E" and "I" refer to the manner in which a person is energized, or where individuals prefer to focus their attention-inwardly or outwardly. The "S" and "N" indicate the process by which a person prefers to receive and take in information or find out about things. The " $T$ " and " $F$ " function identifies a judging process, the manner in which a person makes decisions. The "J" and "P" indicate preferences related to how a person orients himself or herself to the outer world, or the manner in which an individual prefers to live his or her life. The combination of each of the four dimensions gives a person an individual "personality preferences." There is no right or wrong type, because each has its own strengths and weaknesses; a person strong in one area can complement another who is weak in that area.

Even though the MBTI is used extensively in education as a way to determine how best to teach a given class, it has been used very little in agricultural situations. Jose and Crumly (1993) used the MBTI to look for relationships between MBTI styles and financial measures for ranchers and farmers in Nebraska. They found that certain MBTI types had significantly more assets, debt, or off-farm income than other types. The MBTI has also been used as a method of helping farm couples in crisis/stress intervention situations (Horner and Barrett, 1987) and suggests how well they can work together as a team (implications for personnel management). The objective of this study was to determine the MBTI personality preferences of dairy farmers in Utah and compare them with DHI production variables.

\section{MATERIALS AND METHODS}

Dairy farmers were selected from those attending district DHI meetings during the winter of 1998. The MBTI instrument was explained, and producers were asked to sign a consent form allowing use of their information from the instrument. All farmers attending the meetings completed the instrument and represent approximately $30 \%$ of all farms on DHI in Utah. DHI records were also collected from DHI-Provo Computing Center for each dairy for the same time period. A total of 21 out of 125 production variables were selected for examination.

Each instrument was scored, based on the procedures given on the MBTI instrument, summarized, then combined with DHI production variables from each dairy to create one database. The identity of each individual farmer was coded so that it was impossible to identify individuals.

Data were analyzed using the GLM procedure of SAS (1996) with the following model:

$$
\mathrm{Y}_{\mathrm{ijk}}=\mu+\mathrm{T}_{\mathrm{i}}+\mathrm{B}_{\mathrm{j}}+\mathrm{M}_{\mathrm{k}}+\mathrm{TB}_{\mathrm{ij}}+\mathrm{TM}_{\mathrm{ik}}+\mathrm{E}_{\mathrm{ijk}}
$$

where:

$$
\begin{aligned}
\mathrm{Y}_{\mathrm{ijk}} & =\text { DHI variable, } \\
\mu & =\text { overall mean, } \\
\mathrm{T}_{\mathrm{I}}= & \text { treatment effect (MBTI dimension), } \\
\mathrm{B}_{\mathrm{j}}= & \text { breed effect, } \\
\mathrm{M}_{\mathrm{k}}= & \text { effect due to times cows milked per day, } \\
\mathrm{TB}_{\mathrm{ij}} & =\text { interaction between treatment and breed, } \\
\mathrm{TM}_{\mathrm{ik}}= & \text { interaction between treatment and times } \\
& \text { cows milked per day, and } \\
\mathrm{E}_{\mathrm{ijk}}= & \text { residual error. }
\end{aligned}
$$

Effects were considered significant at $P<0.1$, and selected DHI variables represent general areas of milk yield and composition, udder health, reproduction, replacements, genetics, culling, dry cow management, and herd size.

\section{RESULTS AND DISCUSSION}

Sixty (60) male dairy farmers completed the MBTI instrument, and the average MBTI score and age are shown in Table 1. Of the 60 farmers, 51 were from 
Table 1. Average MBTI score and age of individual, by MBTI dimension. The magnitude of the score reflects the average preference for that dimension. The minus sign represents a score in the direction of the $\mathrm{E}, \mathrm{N}$, $\mathrm{F}$, or $\mathrm{P}$ dimension and not a negative value.

\begin{tabular}{lrrl}
\hline Dimension & Score & N & Age (SE) \\
\hline E & -17.6 & 30 & $43.2(2.35)$ \\
I & 26.1 & 30 & $44.7(1.84)$ \\
N & -11.5 & 4 & $55.8(4.39)^{1}$ \\
S & 36.6 & 56 & $43.1(1.50)$ \\
F & -13.7 & 15 & $38.5(2.19)^{1}$ \\
T & 24.8 & 45 & $45.7(1.76)$ \\
J & 24.9 & 37 & $44.3(1.87)$ \\
P & -16.6 & 23 & $43.3(2.48)$ \\
\hline
\end{tabular}

${ }^{1} P=0.03$ within paired dimension.

Holstein farms (85\%) and nine from farms with other breeds, primarily Jersey. Forty-four (73\%) of the herds were milked twice per day and 16 milked three times per day. Farmers were evenly split between the "E" and "I" dimension, while 93\% of the farmers were "S", 75\% "T" and 62\% "J" (Table 1). Distributions were similar for breed and times milked per day within breed. Combinations of MBTI preferences are listed by breed and times cows were milked per day in Table 2 .

The most prevalent personality preferences were ISTJ and ESTJ, accounting for half of all individuals (data not shown). The only difference between the two preferences is in the first dimension. "E" and "I" refer to the manner in which a person is energized or where a person prefers to focus his or her attention-inwardly or outwardly (Myers and McCaulley, 1985). Individuals with the ISTJ preference are good at organizing facts and principles. They prefer to work alone but are responsible and get the job completed right. They will change only if the facts clearly support the change. If ISTJ individuals cannot find a place where they can use their talents they can become rigid, critical of others, and unable to delegate (i.e., only they can do it correctly). In general, they tend not to worry about the impact of a decision on other people.
Individuals that have the ESTJ preference are good at organizing people and objects. They are decisive, outspoken, and self-confident. They love to devise systems and procedures. They tend to make good administrators and orient toward action and the bottom-line of projects. Potential problems may develop because they are prone to make decisions before getting enough information. If they cannot find a place where they can use their talents they can become "know-it-all" experts, refusing to listen and getting impatient with people who don't follow procedures exactly (Myers and McCaulley, 1985).

Individual production variables associated with a significantly higher "I" preference in the "E-I" dimension (Table 4$)$ were peak milk $(P<0.05)$ and mature equivalent milk $(P<0.1)$. Days to first service $(P<0.1)$ and service sire predicted difference for milk $(P<0.05)$ were higher in the "E" preference than in "I." The interaction between the "E" and "I" dimension and times cows are milked per day was significant $(P=0.02)$ for service sire predicted difference for milk, which was significantly higher among those individuals with an "E" preference milking three times per day than for any of the other combinations. The interaction between the "E" and "I" dimension and times cows milked per day was significant $(P=0.02)$ for age at first calving. Those individuals with

Table 2. Number and percentage (in parentheses) of herds for each Myers-Briggs Type Indicator dimension listed by breed and number of times cows milked daily $(n=60)$.

\begin{tabular}{|c|c|c|c|c|c|}
\hline \multirow[b]{2}{*}{ Dimension } & \multicolumn{2}{|c|}{ Holstein } & \multicolumn{2}{|c|}{ Other } & \multirow[b]{2}{*}{ Total } \\
\hline & $2 \times$ & $3 x$ & $2 \times$ & $3 \times$ & \\
\hline $\mathrm{E}$ & $19(50)$ & $7(54)$ & $2(33)$ & $2(67)$ & $30(50)$ \\
\hline $\mathrm{I}$ & $19(50)$ & $6(46)$ & $4(67)$ & $1(33)$ & $30(50)$ \\
\hline $\mathrm{S}$ & $35(92)$ & $12(92)$ & $6(100)$ & $3(100)$ & $56(93)$ \\
\hline $\mathrm{N}$ & $3(8)$ & $1(8)$ & $0(0)$ & $0(0)$ & $4(7)$ \\
\hline $\mathrm{T}$ & $30(79)$ & $9(69)$ & $3(50)$ & $3(100)$ & $45(75)$ \\
\hline $\mathrm{F}$ & $8(21)$ & $4(31)$ & $3(50)$ & $0(0)$ & $15(25)$ \\
\hline $\mathrm{J}$ & $22(58)$ & $9(69)$ & $4(67)$ & $2(67)$ & $37(62)$ \\
\hline $\mathrm{P}$ & 16 & $4(31)$ & $2(33)$ & $1(33)$ & $23(38)$ \\
\hline
\end{tabular}


Table 3. Number of herds (percentage of total in parentheses) for combinations of Myers-Briggs Type Indicator dimensions listed by breed and number of times cows milked $(n=60)$.

\begin{tabular}{|c|c|c|c|c|c|}
\hline \multirow[b]{2}{*}{ Dimension } & \multicolumn{2}{|c|}{ Holstein } & \multicolumn{2}{|c|}{ Other } & \multirow[b]{2}{*}{ Total } \\
\hline & $2 \times$ & $3 \times$ & $2 \times$ & $3 \times$ & \\
\hline IJ & 12 (31.6) & $4(30.8)$ & $3(50.0)$ & $0(0.0)$ & 19 (32) \\
\hline IP & 7 (18.4) & $2(15.4)$ & $1(16.7)$ & $1(33.3)$ & 11 (18) \\
\hline $\mathrm{EP}$ & 9 (23.7) & $2(15.4)$ & $1(16.7)$ & $0(0.0)$ & $12(20)$ \\
\hline \multirow[t]{2}{*}{ EJ } & $10(26.3)$ & $5(38.5)$ & $1(16.7)$ & $2(66.7)$ & $18(30)$ \\
\hline & 38 (100) & $13(100)$ & $6(100)$ & $3(100)$ & $60(100)$ \\
\hline TJ & $19(50.0)$ & 7 (53.8) & $3(50.0)$ & $2(66.7)$ & $31(52)$ \\
\hline $\mathrm{TP}$ & $11(28.9)$ & $2(15.4)$ & $0(0.0)$ & 1 (33.3) & $14(23)$ \\
\hline FP & $5(13.2)$ & $2(15.4)$ & $2(33.3)$ & $0(0.0)$ & $9(15)$ \\
\hline \multirow[t]{2}{*}{ FJ } & $3(7.9)$ & $2(15.4)$ & $1(16.7)$ & $0(0.0)$ & $6(10)$ \\
\hline & 38 (100) & $13(100)$ & $6(100)$ & $3(100)$ & $60(100)$ \\
\hline
\end{tabular}

an "I" preference milking three times per day had higher age at first calving than either the "I" milking two times per day $(P<0.02)$ or "E" persons milking three times daily $(P<0.09)$.

Individuals with an "I" preference were associated with higher milk yield than those individuals with an "E" preference. This may be because " $\mathrm{I}$ " individuals tend not to mind working on one project for long, uninterrupted periods of time and can focus, without loss of attention, on repetitive tasks. Individuals that have an
"E" preference can get impatient with long, slow jobs and like variety and action, and they enjoy having people around and get energy from outside influences. In contrast, "I" individuals like working alone with no interruptions and get their energy internally. These traits would favor an "I" person in the ability to effectively and consistently harvest milk on a dairy. It is interesting that the characteristics associated with the high-achievement cowman (Seabrook, 1984) are similar to those of an "I" individual.

Table 4. Least squares means (SE in parentheses) of DHI variables for the MBTI dimensions of extravert (E) versus introvert (I).

\begin{tabular}{|c|c|c|c|}
\hline \multirow[b]{2}{*}{ DHI variable } & \multicolumn{2}{|c|}{ MBTI dimension } & \multirow[b]{2}{*}{ Probability } \\
\hline & $\mathrm{E}$ & I & \\
\hline Total cows & $147(38.0)$ & $199(38.1)$ & NS \\
\hline Cow's 1st lactation, \% & $34.1(2.08)$ & $32.5(2.09)$ & NS \\
\hline Milk per cow, kg & $22.4(1.53)$ & $25.5(1.53)$ & NS \\
\hline $3.5 \% \mathrm{FCM}, \mathrm{kg}$ & $24.3(1.55)$ & $27.2(1.55)$ & NS \\
\hline RHA ECM, ${ }^{1} \mathrm{~kg}$ & $8891(455)$ & $9852(456)$ & NS \\
\hline Peak milk, kg & $34.1(1.55)$ & 39.0 & * \\
\hline $\mathrm{MEM},{ }^{1} \mathrm{~kg}$ & $8870(464)$ & $10,021(465)$ & $\dagger$ \\
\hline $\mathrm{MEF},{ }^{1} \mathrm{~kg}$ & $346(16.5)$ & $381(16.5)$ & NS \\
\hline MEP, $\mathrm{kg}^{1}$ & $314(14.5)$ & $342(14.5)$ & NS \\
\hline Last calving interval, mo & $13.8(0.31)$ & $13.5(0.31)$ & NS \\
\hline Days to first service & $93.9(4.42)$ & $82.6(4.42)$ & $\dagger$ \\
\hline Days open & $152.1(5.87)$ & $139.2(5.87)$ & NS \\
\hline Heat detection, \% & $53.5(2.73)$ & $57.8(2.73)$ & NS \\
\hline Age 1st calving, mo & $25.7(0.62)$ & $26.1(0.62)$ & NS \\
\hline Average SCS & $2.61(0.16)$ & $2.51(0.16)$ & NS \\
\hline Average days dry & $61.6(1.92)$ & $61.6(1.93)$ & $\mathrm{NS}$ \\
\hline $\mathrm{USDA}^{1} \%$ & $63.4(7.62)$ & $68.9(7.66)$ & NS \\
\hline Service sire PDM, kg & $755(40.7)$ & $632(41.8)$ & * \\
\hline Herd pregnancy, $\%$ at X DIM ${ }^{1}$ & 22.8 & $24.8(1.8)$ & NS \\
\hline Culling \% & $30.6(2.15)$ & $32.1(2.16)$ & NS \\
\hline DIM & $203.2(6.43)$ & $199.94(6.44)$ & NS \\
\hline
\end{tabular}

${ }^{1} \mathrm{RHA} \mathrm{ECM}=$ Rolling herd average energy-corrected milk, $\mathrm{MEM}=$ mature equivalent milk, $\mathrm{MEF}=$ mature equivalent pounds of fat, MEP = mature equivalent pounds of protein, USDA = percentage of records usable by USDA, Herd pregnancy, $\%$ at X DIM = percentage of herd that is pregnant by the DIM goal set by the dairy producer $(89.6 \pm 8.48)$.

$$
\begin{aligned}
& \dagger P \leq<=0.10 . \\
& * P \leq<=0.05 . \\
& * * P \leq<=0.01 .
\end{aligned}
$$


Individuals with a preference for the "I" dimension also tended toward doing a better job in the DHI variables associated with reproduction. This may be because those individuals with a preference for the "E" dimension prefer variety, action, and focusing on administrative activities, such as managing people and developing farm goals on reproduction, rather than dealing directly with cows and the "hands-on" reproductive process.

An "I" individual may have difficulties managing other areas of the farm when cows are milked two versus three times daily, because age at first calving was higher for those farms that milked cows three times daily ( 27.3 vs. $25.0, P<0.02$ ). This is in contrast to farms managed by "E" individuals, where no difference in age at first calving was found between those farms that milked cows two versus three times daily. This could be an organization/management skill of individuals with an " $\mathrm{E}$ " preference. It was interesting that on farms managed by individuals with the "E" preference, service-sire-predicted difference for milk of farms milking cows twice daily was lower than for farms milking three times daily ( 1855 vs. $1475, P=0.018$ ), whereas on farms managed by individuals with the "I" preference, there was no difference between times cows were milked and sire-predicted difference for milk. The "E" person possibly relies more on talking and getting information from external sources and may have been influenced more by a salesperson than an "I" individual. Sire selection does not always follow hard rules/facts, and an "I" individual would not change unless facts demonstrated a need or a better way.

The "S" and " $\mathrm{N}$ " dimension describes how individuals take in information and find out about things (Myers and McCaulley, 1985). It was heavily skewed (94\%) toward the "S" preference; therefore, individual DHI production variables associated with the "S" and "N" dimension are not shown due to the small number of "N" farmers. Individuals with a preference for "N" may let their intuition (gut reaction) toward decision-making overcome their sensory methods (factual, concrete, present-oriented) in how they make decisions.

Individual DHI production variables associated with significant differences in the "T" and " $F$ " dimension (Table 5) were percentage of herd pregnant by the DIM goal $(89.6 \pm 8.48)$ set by the dairy farmer $(P<0.01)$, days dry $(P<0.10)$, and heat detection percentage $(P$ $<0.10)$. These variables were all higher for the " $F$ " preference, whereas percentage of records usable by USDA $(P<0.05)$ and days open $(P<0.05)$ were higher for the "T" preference. The interaction between the " $T$ " and " $\mathrm{F}$ " dimension and times milked per day was significant for days open $(P<0.10)$, heat detection percent- age $(P<0.05)$, and percentage pregnant by DIM goal $(P<0.05)$.

The "T" and "F" dimension describes how a person makes decisions (Myers and McCaulley, 1985). Individuals with a preference for " $T$ " are logical, analytical, less concerned with people's feelings, may hurt them unintentionally, and are tough-minded. "F" individuals are strongly influenced in their decision-making by how it will impact other people. They are sympathetic and compassionate. The extremes for this dimension are logical thinking compared with feelings and emotions. Surprisingly, those farmers with an "F" preference seemed to manage herd reproduction better, as measured by higher heat detection percentage, lower days open, and a higher percentage of herd pregnant by 89.6 DIM than those farmers with a preference for the "T" dimension. However, they had fewer animals with records usable by USDA. The reason for a lower percentage of cows pregnant by the DIM goal for farmers with a preference for the "T" dimension could be that they may not see the need to adhere to that goal. In addition, a higher percentage of cows with usable records for those " $T$ " individuals may be reflective of a higher proportion of registered animals in herds with breeds other than Holstein.

Individual DHI production variables associated with higher "P" preferences in the " $\mathrm{J}$ " and "P" dimension (Table 5) were age at first calving $(P<0.05)$ and percentage of herd pregnant by 89.6 DIM $(P<0.10)$. The "J" preference was higher than the "P" in percentage of cows with usable records in USDA $(P<0.05)$. The "J" and "P" dimension and times cows are milked per day also differed for total cows in the herd $(P<0.10)$, days open $(P<0.05)$, age at first calving $(P<0.05)$, and service-sire-predicted difference for milk $(P<0.05)$ (Table 6).

The "J" and "P" dimension reflects how individuals orient themselves toward the outer world (Myers and McCaulley, 1985). Those individuals with a "J" preference are typically organized, prefer schedules, and like to finish one task/project before starting another. They may not notice when new things need to be done. Individuals with a "P" preference are " 11 th hour" or lastminute individuals. They like to take in information for a long time before making a decision (postpone it) and prefer being casual, flexible, and open-ended. The lack of more differences in DHI variables is surprising given the need for organization and timely task completion in managing a dairy. However, those individuals with a preference for the "J" dimension had a higher percentage of records usable by USDA than those with a preference for "P" ( 74.9 vs. $49.6 \%, P<0.05)$. This may be reflective of the need for organization and to have task closure/completion. This may also have an added 
Table 5. Least squares means (SE in parentheses) of DHI variables for the MBTI dimensions of thinking (T) versus feeling (F).

\begin{tabular}{|c|c|c|c|}
\hline \multirow[b]{2}{*}{ DHI variable } & \multicolumn{2}{|c|}{ MBTI dimension } & \multirow[b]{2}{*}{ Probability } \\
\hline & $\mathrm{T}$ & $\mathrm{F}$ & \\
\hline Total cows & $165(31.3)$ & $195(53.4)$ & NS \\
\hline Cow's 1st lactation, \% & $34.5(1.6)$ & $29.8(2.8)$ & NS \\
\hline Milk per cow, kg & $24.0(1.28)$ & $24.6(2.18)$ & NS \\
\hline $3.5 \% \mathrm{FCM}, \mathrm{kg}$ & $25.9(1.31)$ & $25.9(2.23)$ & NS \\
\hline RHA ECM ${ }^{1} \mathrm{~kg}$ & $9432(397)$ & $9250(676)$ & NS \\
\hline Peak milk, kg & $36.5(1.40)$ & $36.9(2.39)$ & NS \\
\hline $\mathrm{MEM},{ }^{1} \mathrm{~kg}$ & $9476(408)$ & $9437(695)$ & NS \\
\hline $\mathrm{MEF},{ }^{1} \mathrm{~kg}$ & 369 (14.4) & $354(24.6)$ & NS \\
\hline $\mathrm{MEP},{ }^{1} \mathrm{~kg}$ & $330(12.7)$ & $323(21.6)$ & NS \\
\hline Last calving interval, mo & $13.6(0.25)$ & $13.8(0.43)$ & NS \\
\hline Days to first service & $89.0(3.77)$ & $87.9(6.41)$ & NS \\
\hline Days open & $150.3(4.79)$ & $131.2(8.14)$ & * \\
\hline Heat detection, \% & $53.8(2.17)$ & $62.0(3.69)$ & $\dagger$ \\
\hline Age 1st calving, mo & $25.6(0.54)$ & $26.1(0.92)$ & NS \\
\hline Average SCS & $2.59(0.13)$ & $2.42(0.22)$ & NS \\
\hline Average days dry & $59.9(1.55)$ & $65.3(2.64)$ & $\dagger$ \\
\hline $\mathrm{USDA}^{1} \%$ & $75.1(5.86)$ & $49.7(10.46)$ & * \\
\hline Service sire PDM, kg & $728(37.5)$ & $609(63.0)$ & NS \\
\hline Herd pregnancy, $\%$ at X DIM ${ }^{1}$ & $21.8(1.37)$ & $29.8(2.33)$ & ** \\
\hline Culling \% & $31.6(1.72)$ & $30.8(2.92)$ & NS \\
\hline DIM & $202.3(5.17)$ & $196.4(8.81)$ & NS \\
\hline
\end{tabular}

${ }^{1}$ RHA ECM = Rolling herd average energy-corrected milk, MEM = mature equivalent milk, $\mathrm{MEF}=$ mature equivalent pounds of fat, $\mathrm{MEP}$ = mature equivalent pounds of protein, USDA = percentage of records usable by USDA, Herd pregnancy, \% at X DIM = percentage of herd that is pregnant by the DIM goal set by the dairy producer $(89.6 \pm 8.48)$.

$$
\begin{aligned}
& \dagger P \leq<=0.10 . \\
& * P \leq<=0.05 . \\
& * * P \leq<=0.01 .
\end{aligned}
$$

benefit in that individuals that know all young stock and cows by number or name (for our situation that means "identified") have been shown to have lower bulk tank SCC (Barkema et al., 1999).

Individuals with combinations of "E" and "I" and "J" and "P" are associated with how others see them and how they respond to change (Myers and McCaulley, 1985). Individuals with a combination preference of " $E$ " and "P" had herds with 7 to $10 \mathrm{~kg}$ less of $3.5 \% \mathrm{FCM}$ or 1820 to $2500 \mathrm{~kg}$ RHA less ECM than any other combination of "E" and "I" and " $\mathrm{J}$ " and "P" dimensions (data not shown). Those herds also had longer days dry and lower percentage of cow records that were usable by USDA (73.9 vs. $21.5 \%, P=0.013$ ). These "EP" individuals are called adaptable extraverts. They are characterized as active, energetic, and sociable individuals who seek new experiences. They seem to be less favorably associated with those measures of herd performance. They make up $20 \%$ of the individuals in this database.

The $\mathrm{T}$ and $\mathrm{F}$ and $\mathrm{J}$ and $\mathrm{P}$ combinations are measures of how a person supervises another and the preferred leadership style (Myers and McCaulley, 1985). The TJ combinations are logical decision makers, TP are adaptable thinkers, FP are gentle types, and FJ are benevolent administrators. Individuals with a preference for
"TJ" had significantly higher percentage of records usable by the USDA and service-sire-predicted difference for milk. Individuals with an "FP" preference had a significantly higher percentage of herd pregnant by 89.6 DIM.

\section{CONCLUSIONS}

Out of a possible 16 MBTI combinations, $50 \%$ of the individuals in this study were grouped into two preferences, ISTJ and ESTJ. Individuals with a preference for the "I" dimension were associated with higher peak and mature equivalent milk yields. Individuals with a preference for " $F$ " seemed to do a better job managing herd reproduction. Individuals with a "T" or "J" preference had higher percentages of cows with records usable for USDA and individuals with a preference for "P" had cows with higher average age at first calving than individuals with a preference for "J."

The concept of using MBTI instruments as a gauge for management has merit, but using DHI production variables may have limited use because cause-and-effect relationships between managing ability and outcome are hard to assess. A better comparison may be in the areas of labor and business management as de- 
Table 6. Least squares means (SE in parentheses) of DHI variables for the MBTI dimensions of judging $(\mathrm{J})$ versus perceiving $(\mathrm{P})$.

\begin{tabular}{lccc}
\hline & \multicolumn{2}{c}{ MBTI dimension } & \\
\cline { 2 - 3 } DHI variable & $\mathrm{J}$ & $\mathrm{P}$ & Probability \\
\hline Total cows & $191(32.0)$ & $142(45.6)$ & $\mathrm{NS}$ \\
Cows 1st lactation, \% & $33.7(1.77)$ & $32.5(2.52)$ & $\mathrm{NS}$ \\
Milk per cow, kg & $24.1(1.34)$ & $23.5(1.91)$ & $\mathrm{NS}$ \\
$3.5 \%$ FCM, kg & $25.9(1.36)$ & $25.4(1.95)$ & $\mathrm{NS}$ \\
RHA ECM, ${ }^{1} \mathrm{~kg}$ & $9411(411)$ & $9236(585)$ & $\mathrm{NS}$ \\
Peak milk, kg & $36.8(1.43)$ & $36.0(2.04)$ & $\mathrm{NS}$ \\
MEM, ${ }^{1} \mathrm{~kg}$ & $9552(420)$ & $9206(598)$ & $\mathrm{NS}$ \\
MEF, ${ }^{1} \mathrm{~kg}$ & $369(14.9)$ & $353(21.2)$ & $\mathrm{NS}$ \\
MEP, ${ }^{1} \mathrm{~kg}$ & $332(13.1)$ & $319(18.6)$ & $\mathrm{NS}$ \\
Last calving interval, mo & $13.7(0.26)$ & $13.5(0.37)$ & $\mathrm{NS}$ \\
Days to first service & $89.7(3.82)$ & $86.2(5.43)$ & $\mathrm{NS}$ \\
Days open & $150.3(4.95)$ & $136.6(7.03)$ & $\mathrm{NS}$ \\
Heat detection, $\%$ & $55.1(2.36)$ & $56.5(3.35)$ & $\mathrm{NS}$ \\
Age 1, calving, mo & $25.1(0.52)$ & $27.1(0.75)$ & $*$ \\
Average SCS & $2.51(0.13)$ & $2.62(0.19)$ & $\mathrm{NS}$ \\
Average days dry & $60.4(1.59)$ & $63.1(2.26)$ & $\mathrm{NS}$ \\
USDA $^{1} \%$ & $74.9(6.31)$ & $49.6(9.60)$ & $*$ \\
Service sire PDM, kg & $703(37.4)$ & $645(53.7)$ & $\mathrm{NS}$ \\
Herd pregnancy, \% at X DIM ${ }^{1}$ & $22.5(1.49)$ & $26.0(2.12)$ & $\dagger$ \\
Culling \% & $30.3(1.80)$ & $33.6(2.56)$ & $\mathrm{NS}$ \\
DIM & $201.9(5.49)$ & $199.3(7.81)$ & $\mathrm{NS}$
\end{tabular}

${ }^{1}$ RHA ECM $=$ Rolling herd average energy-corrected milk, $\mathrm{MEM}=$ mature equivalent milk, $\mathrm{MEF}=$ mature equivalent pounds of fat, MEP = mature equivalent pounds of protein, USDA = percentage of records usable by USDA, Herd pregnancy, $\%$ at X DIM = percentage of herd that is pregnant by the DIM goal set by the dairy producer $(89.6 \pm 8.48)$.

$$
\begin{aligned}
& \dagger P \leq<=0.10 . \\
& * P \leq<=0.05 . \\
& * * P \leq<=0.01 .
\end{aligned}
$$

scribed in studies of other farm types (Horner and Barrett, 1987; Jose and Crumly, 1993). Neither of those was assessed in this study, but they should be strongly considered in future studies.

\section{ACKNOWLEDGMENTS}

The cooperation of the dairy farmers of Utah in taking the time to complete the MBTI instrument is greatly appreciated.

\section{REFERENCES}

Barkema, H. W., J. D. Van der Ploeg, Y. H. Schukken, T. J. G. M. Lam, G. Benedictus, and A. Brand. 1999. Management style and its association with bulk milk somatic cell count and incidence rate of clinical mastitis. J. Dairy Sci. 82:1655-1663.

Bascom, S. S. 1996. Managing the cow culling decision process. M.S. Thesis, Univ. New Hampshire, Durham.

Beaudeau, F. 1995. Cow's health and farmer's attitude towards the culling decision in dairy herds. Ph.D. Thesis, Wageningen Agric. Univ., Wageningen, The Netherlands.

Bigras-Poulin, M., A. H. Meek, and S. W. Martin. 1985. Attitudes, management practices, and herd performance-a study of Ontario dairy farm managers. II. Associations. Prev. Vet. Med. 3:241-250.
Bonham, A. 1988. Learning style instruments: Let the buyer beware. Lifelong Learning: An Omnibus of Practice and Research 11(6):12-15.

Cano, J., B. L. Garton, and M. R. Raven. 1992. Learning styles, teaching styles and personality styles of preservice teachers of agricultural education. J. Agric. Education 33(1):46-52.

Ford, S. A., and J. S. Shonkwiler. 1994. The effect of managerial ability on farm financial success. Agric. and Resource Economics Rev. 23:150-157.

Gregorc, A. F. 1979. Learning/teaching styles: Potent forces behind them. Educational Leadership 36(4):234-236.

Horner, J. T., and L. A. Barrett. 1987. Personality types of farm couples-implications for intervention strategies. Fam. Strengths 8/9:131-142.

Jose, H. D., and J. A. Crumly. 1993. Psychological type of farm/ranch operators: Relationship to financial measures. Rev. Agric. Econ. 15(1):121-132.

Lawrence, G. 1984. A synthesis of learning style research involving the MBTI. J. Psychological Type 8:2-15.

Myers, I. B., and M. H. McCaulley. 1985. Manual: A guide to the development and use of the Myers-Briggs Type Indicator. Consulting Psychologists Press, Palo Alto, CA.

SAS User's Guide: Statistics, Version 6.12 Edition. 1996. SAS Inst., Inc., Cary, NC.

Seabrook, M. F. 1984. The psychological interaction between the stockman and his animals and its influence on performance of pigs and dairy cows. Vet. Rec. 115:84-87.

Tarabla, and Dodd. 1990. Associations between farmers' personal characteristics, management practices and farm performance. $\mathrm{Br}$. Vet. J. 146(2):157-164. 